\title{
NMES
}

New Middle Eastern Studies

ISSN: 2051-0861

Publication details, including guidelines for submissions:

https://journals.le.ac.uk/ojs1/index.php/nmes

\section{Hegemony and the Interest of Egypt's Business Elite in Post-Mubarak Press}

Author(s): Maher Hamoud

To cite this article: Hamoud, Maher (2019) "Hegemony and the Interest of Egypt's Business Elite in Post-Mubarak Press", New Middle Eastern Studies 9 (1), pp. 115-132.

Online Publication Date: 25 March 2019

\section{Disclaimer and Copyright}

The NMES editors make every effort to ensure the accuracy of all the information contained in the journal. However, the Editors and the University of Leicester make no representations or warranties whatsoever as to the accuracy, completeness or suitability for any purpose of the content and disclaim all such representations and warranties whether express or implied to the maximum extent permitted by law. Any views expressed in this publication are the views of the authors and not the views of the Editors or the University of Leicester.

Copyright New Middle Eastern Studies, 2019. All rights reserved. No part of this publication may be reproduced, stored, transmitted or disseminated, in any form, or by any means, without prior written permission from New Middle Eastern Studies, to whom all requests to reproduce copyright material should be directed, in writing.

\section{Terms and Conditions}

This article may be used for research, teaching and private study purposes. Any substantial or systematic reproduction, re-distribution, re-selling, loan or sub-licensing, systematic supply or distribution in any form to anyone is expressly forbidden.

The publisher does not give any warranty express or implied or make any representation that the contents will be complete or accurate or up to date. The accuracy of any instructions, formulae and drug doses should be independently verified with primary sources. The publisher shall not be liable for any loss, actions, claims, proceedings, demand or costs or damages whatsoever or howsoever caused arising directly or indirectly in connection with or arising out of the use of this material. 


\title{
Hegemony and the Interest of Egypt's Business Elite in Post- Mubarak Press
}

\author{
Maher Hamoud*
}

\begin{abstract}
This article aims at critically analysing the hegemony of Egypt's business elite and the private press they own following Mubarak's fall. Hegemony requires the exercise of power to maintain consent under changing conditions such as the 2011 uprising and the 2013 military coup. This study answers the question of "why and how Egypt's business elite controls the post-Mubarak press?". Situated within the interdisciplinary domain of "critical political economy of communication", this article focuses on the two most popular privately-owned newspapers al-Masry al-Youm and al-Watan. Interviews with high-profile sources have been conducted and embedded into the research. Findings show that the Egyptian private press, particularly in the post-Mubarak era, is closely controlled by the business elite in favour of their interests, and indirectly in favour of the political elite - whether civilian or military. The sector's hegemonic position was briefly shaken by the 2011 uprising, then quickly maintained and reinforced before the 2013 coup.
\end{abstract}

Keywords: Egyptian Economy; Business Elite; Media Politics; Mubarak; Morsi; Al-Sisi; Revolution; Military Coup

\section{Introduction}

One of Egypt's most influential figures is Magdy al-Gallad. He was the editor-in-chief of one of Egypt's top privately owned newspapers, namely al-Masry al-Youm from 2005 to 2012, before occupying the same position at Egypt's other top private newspaper, al-Watan, from 2012 until present. The politically well-connected editor wrote in 2009 a eulogy article entitled "Life on the Shoulders of Gamal Mubarak", polishing Hosni Mubarak's son as a probable future president about two years before the January uprising in 2011. When reading Denis McQuail discussing the development of the newspapers' industry in the 17th century, one can draw similarities that still exist until today when we focus on al-Gallad's work. Newspapers were an extension into the public domain of an activity that has long taken place for governmental, diplomatic or commercial as well as for private purposes. The early newspaper was marked by its regular appearance, commercial basis and public character. Thus, it was used for information, record, advertising, diversion and gossip (McQuail 2010: 27-28). Al-Masry al-Youm and al-Watan might appear from a distance as modern as the wellestablished international newspapers. However, having a closer critical look, one might have

\footnotetext{
*Maher Hamoud; Department of Conflict and Development Studies, Ghent University, Universiteitsstraat 8, Ghent 9000, Belgium. Email: maher.hamoud@ugent.be.
} 
a strong sense of the 17-century journalism as McQuail describes it, disguised in a twentyfirst-century design and print quality.

Regarding the 2011 uprising, it is true that media accounts have elevated the Tahrir episode to the status of a "pure event". Echoing a Biblical clash between Good and Evil, where Tahrir became the place where al-Sha'ab (the people), fought a victorious battle against al-Nizam (the regime) (Zemni, De Smet and Bogaert 2013). The fall of Mubarak on 11 February 2011 was not the fall of his regime's elites, contrary to how it was portrayed in local and international media. The political and business elites had been in control of the state's institutions for decades before that day. They were coordinating with each other to protect the political and economic gains they had made since Egypt's full independence from colonialist Britain in 1952. Over the years until the fall of Mubarak, they have changed faces and control mechanisms several times. Among the most important tools in the elites' hands were the state-run media, the private media, and the private press - the latter is the focus of this research.

One of the major outcomes of Egypt's uprising in 2011 was bringing Mohamed Morsi to power. He was a civilian and democratically elected president from the Muslim Brotherhood in 2012, whom was unacceptable to the historically politically engaged Egyptian army. A military coup in 2013 was the reaction to his election. It was also supported by the masses who headed to the streets in unprecedented numbers across the country, regardless of existing aspirations for democracy that brought Mubarak down only two years earlier. News agendas controlled by political, business and military elites - besides the fatal political mistakes of the Muslim Brotherhood - were the main reasons behind the emergence of a mass support for this coup. This article critically discusses the political economy behind controlling news agendas in Egypt during that particular period in the private press market.

This research asks the question of "why and how Egypt's business elite controls the post-Mubarak press?". It provides answers by going through and analysing relevant literature critically covering Egypt's business elite and its private media sector, and conducting interviews with media stakeholders. In order to place these answers in a historical context leading up to the 2013 coup, I also discuss the business elite's initial position before the 2011 uprising as a power group interested in protecting their privileges in a free-market economy. In the under-researched area of the political economy of Egyptian media, the findings of this research provide us with explanations for an important aspect of the dynamics of power relations between the political and business elites. Understanding these dynamics will help us understand why a newspaper like al-Masry al-Youm was founded in 2004, and why there was a need for another one like al-Watan to be founded in 2012. It is also almost equally important to understand the profiles of some business tycoons, and of no less importance, the profiles of chief editors working for them.

\section{Theoretical Approach and Research Methodology}

In a private media sector, investors tend to make arrangements with governments because they share agendas and benefit mutually from cooperation (Hardy 2014). This critical view of the private media is interestingly supported by the free-market media economist Gillian Doyle who argues that since the early days of printing, the ability to communicate with mass 
audiences has been subject to many forms of intervention by state authorities. She also adds that media industries are affected not only by "normal" economic and industrial policy concerns, like growth and efficiency, but also by a range of special considerations that reflect the socio-political and cultural importance of mass communication (2013: 165). This article situates itself within the field of critical political economy of communication, which I consider essential to understanding Egypt's private press market concerning the presence of hegemony and social relations.

In this sense, the instrumental character of media becomes obvious. Not only when one investigates the relationships between the owners of media and the ruling elite, but also when one considers that the content produced is most often loyal to the regime (Richter and Gräf 2015: 32). Therefore, it is necessary to follow a critical approach that questions the media as an attack of money and power, and in turn, as a structure that the elites use to dominate a society (Habermas 1987: 375). As such, Vincent Mosco argues that a hegemonic discourse requires the exercise of media power to maintain consent under changing political conditions. Here, communication plays a central role in hegemony as both conventional and new media (e.g. social media outlets) are vital to the successful maintenance of hegemonic control, as well as to resistance and the construction of counter-hegemonies (Mosco 2009: 209-210). This understanding of political economy from the perspective of media and power relations is the key to studying the Egyptian private press market. Understanding this market goes through addressing the political economy of the country and the power of its business elite under changing conditions, including the brief challenge they experienced during the 2011 uprising and how they counter-attacked and repressed that challenge by supporting the 2013 coup. This narrative goes hand in hand with a critical discussion of their historical and contemporary backgrounds.

Based on the chosen theoretical framework mentioned above, the methodology of this research is designed to conduct a critical qualitative analysis of Egypt's business elite and their hegemonic political interests in the press they dominate. The analysis discusses the existing literature covering Egypt's political economy in general and the media market in particular since the 1950s until present. However, extra attention will be particularly given to the period from the early 2000s until present, taking the country's top two private newspapers, al-Masry al-Youm and al-Watan, their owners and their editors as case studies.

Given the scarcity in academic literature covering Egypt's political economy of media, particularly around the coup period, this article incorporates non-academic sources like thinktank reports, and carefully utilised journalistic sources. Additionally, this article benefits from responses by Egyptian senior media professionals interviewed for this research. These responses were not edited and are embedded into the article without any modifications/alterations - as they are highly relevant to the arguments and analyses put forward throughout the article. Hence, the reader should be able to distinguish their voices in the article, as senior eyewitnesses from within the press industry, from the voices of the scarce academic literature on the coup period, the think-tanks and journalistic texts. These interviews are important because of the special access to confidential information each interviewee has, which is not usually available to average journalists. The sources I interviewed are all influential media professionals who provide a significant portion of the daily news production in Egypt's private press market. I interviewed five of these high- 
profile sources via email for this study. Four of them are influential journalists and editors, and one is a CEO of a private media company. Their ages range between mid-30s and late 40 s. Some of them work for the two sample newspapers studied here. I provide relatively little details about them to avoid exposing them to security risks - which is a serious possibility considering that they are all still living in the country. Egypt is considered as one of the worst jailers of journalists worldwide (CPJ 2015). Therefore, I decided to process their interviews anonymously and refer to them by using gender-neutral pseudonyms such as Nour Magdy, Alaa Zakareya, Reda Abbas, Wesam Shawkat, and Ihsan Sameer.

\section{The Business Elite and Their Interest in Press Control}

Understanding the issue of economic injustice and the role of Egypt's business elite as an ally of the political elite for the sake of protecting both elites' benefits can play a significant role in understanding what was happening in Egypt at that moment in history around the time of the 2013 military coup. One of the most valuable hegemonic tools at the hands of the Egyptian elite was the private press they owned, and control over it ensured the old regime to survive even after the fall of Mubarak in 2011. Egypt's business elite and their relation to the state are intimately connected to the process of accumulating capital in their hands under a free market economy. Accumulation of capital always needs certain political decisions to help and reinforce its ongoing process. David Harvey argues that the private sector always seeks to maximize its benefits/profits. This can counteract with the political elite or the two forces may simply reinforce each other. However, the process of cooperation between political and business elites is complex as it is hard to manage either sphere of life - except indirectly (Harvey 2003: 28). In Egypt's case, reinforcement is common, as the rest of this article discusses in detail. We can see that the relationship between the business and political elites in the country is in similar position to Harvey's understanding. Both entities - with their controlled state and private press - support an aggregate trend: the free market economy. And clearly the institutional arrangements embedded within the state have an influential role to play in setting the stage for capital accumulation.

We can see the dynamics between the political and business elites in Mubarak's politics as a sort of continuation of Anwar Sadat's Infitah (Open Door) policy. In Mubarak's times, we can single out, as one example from many, the steel tycoon Ahmed Ezz, who managed to accumulate colossal wealth in a relatively short period of time. Ezz was allowed to dominate the Egyptian steel market, while at the same time playing a significant political role in Mubarak's National Democratic Party (NDP) by holding the position of the Secretary General of Organization. One tycoon with his wealth, power and several arms in the business sector and political domain was a leading player in the process of political enforcement in a top-down manner, as it appeared in both parliamentary elections of 2005 and 2010. Fraud occurred in both elections; however the later one was more evident in favour of the NDP.

The relationship between capital and political power seems to appear as a set of mutual interests, where the accumulation of control over the political sphere is an important goal. I argue that today's Egypt has a top-down enforced neoliberal model as many evident realities highlight. This model and the injustices it brought were a reason for the people to rise against the ruling elites in 2011. However, the 2011 January uprising was not simply born at that 
moment in history nor did it end with the fall of Mubarak (Abdelrahman 2015). It is a chapter in recent history of free market dynamics, local and global, that led to the emergence of contemporary Egypt as an "emerging market" in the international political economic system. The rise of political activism and public discontent can be traced to at least ten years before the masses poured out onto the squares demanding the "fall" of Mubarak and his regime. However, only Mubarak was removed but his regime and legacy remained. The current political instability in Egypt is more likely to continue for the foreseeable future, since the reasons for the uprising's eruption are still there, as Maha Abdelrahman argues:

\begin{abstract}
After the initial euphoria and laudatory comments, the supposedly victorious masses were soon relegated to back seat while the focus returned to traditional political actors: the military, the [Muslim] Brotherhood [ousted by the 2013 military coup] and regional powers. The millions and their continuing struggle receive cursory attention and only in so far as they are seen to have been subdued and defeated by counter-revolutionary forces $[\ldots]$ Increasing poverty, high unemployment rates and a youth bulge combined with the absence of political freedom under an authoritarian regime are by now the stable ingredients of the mainstream narrative of the causes of the Egyptian uprising (Abdelrahman 2015: 3-4).
\end{abstract}

The crucial role and power of private press in Egyptian political life should be evaluated in light of the context summarised above. As the private media is still powerful and controlled by the same elites, the masses will keep receiving the same cursory attention.

The media play an important role in conveying political and economic discourses to the public. Egypt's private media and those who own it are in no different position, as they do use frames conveying their messages to the masses attempting to shape their political compass, just as it happens in any form of media. Journalists have been found to use a multitude of methods to frame the news. Commonly used themes include emphasizing conflict, an emotional aspect of a story, and/or grim economic consequences. These frames can promote a particular problem definition, causal interpretation, or moral evaluation (Entman 1993) and thus influence debates and structure the political outcomes. Throughout this article, I argue that news production is influenced by frames, which in general match with interests of private newspapers' owners - both politically and economically (Ratta, Sakr, and Skovgaard-Petersen 2015). Regardless of this proven influence of news coverage on the public, we still have to deal case by case learning about how this influence prevails within certain news agendas. We also learn from each case how politicians - including members of the business elite in the Egyptian case - formulate their responses to both the news agendas they control and the public they target (Benson 2004). We should also pay attention to the fact that different news agendas have different influences on citizens and politics (Cook 2006). However, in the case of the Egyptian media market, although citizens have access to several news outlets, agendas are mostly similar in their political and economic interests.

The media ownership concentration is a significant variable of great importance in terms of the power it brings to the owner. This is particularly the case, if media power can be used to project political influence, as an investor would aspire to gain. In their book "Arab Media Moguls", Naomi Sakr et al. (2015) see the Middle East as a fertile ground for media moguldom, where a general business tycoon - coming from the business elite with all 
associations with the political one - invests in the private media. This phenomenon is particularly applicable to the Egyptian case. As it happened in many countries in the region, the Egyptian media tycoons have emerged with the opportunities afforded by steps towards the liberalisation and privatisation of the media sector - which I would not separate from the liberalisation and privatisation of the economy in general - and with the rise of an expanding media market. The media tycoons rose under the watchful eyes of political authoritarianism, and they made sure not to challenge the rulers directly.

The autocratic rulers envisaged media regulations and censorship, not to prevent media concentration but to curb political opposition and to foster a submissive public. The authoritarian power-holders of Egypt could live with the rise of media tycoons, and the media tycoons could live with them (Cook 2006). However, I argue that particularly in the Egyptian case, the media tycoons did not rise entirely organically in response to liberalization; rather they were indirectly, or maybe even directly, pushed to play that role and bring about a submissive mass to their counterparts in power, the political elite. Ihsan Sameer, one of the interviewees, confirms the presence of such a relation between the business and the political elites and says that "Yes, I believe that this relation exists, however in different variations. The business community desires to support its own activities through influencing the economic press". I also argue that profitability from media investments - especially in Egypt, where business tycoons like Salah Diab and Mohamed al-Amin are strong cases - is not a priority in comparison to other non-media investments (These two cases are to be discussed in detail later in this article). There are indeed increasing trends towards media concentration and no effective controls against that. Ownership concentration has spurred the downswing of pluralism in Egyptian media. For example, the prominent outspoken journalist Ibrahim Eissa, who founded al-Tahrir TV right after the fall of Mubarak, sold it to Suleiman Amer, a businessman closely connected to Mubarak's elite (Hafez 2015).

Skovgaard-Petersen (2015) defines a media tycoon as a person who owns and operates major media companies, who takes entrepreneurial risks, and who conducts these media businesses in a personal or eccentric style. A definition I agree with, however, I would like to make clear that in the case of Egypt, the risks are not necessarily high, since the gains in other non-media investments rise due to connections to the inner circle of political power. Reda Abbas goes along the same lines saying that "A quick look at the media scene in Egypt, will tell you that all private media is owned by big business names. They all have huge investments in areas other than the media, and all have a foot in the media scene by holding one or more media outlets, and they defiantly control that space". This explains how an Egyptian media tycoon would win a favour with the political elite, and hence have more access to economic power. We can see this clearly in the cases of Diab and his investment in al-Masry al-Youm newspaper, and al-Amin in al-Watan newspaper and several TV networks.

Profit-seeking cannot be an overriding expectation, because distortions in the advertising market and restrictions on editorial content do undermine the commercial potential of media operations. Controlling a network of media is a good way to demonstrate loyalty and thus carry favours with the rulers of a country (Skovgaard-Petersen 2015), which is the main goal of the investment. In Mubarak's era, all the major media tycoons tended to be close to the regime. However, being close does not mean that they approved of the regime or that they actively sought its patronage. Rather, it was often an inevitable consequence of 
the economic importance and interests of the business groups they were heading (Guaaybess 2015). And here comes the role of newspapers like al-Masry al-Youm and al-Watan and their owners. Nour Magdy elaborates a bit more saying that "Many businessmen, whether those who started their media outlets before or after the 25th of January 2011, used them [media outlets] to achieve certain goals, or to deliver certain messages to the recipients. This is very clear when comparing the way famous broadcasters and writers change their tones according to the outlet they're working for. In addition to this, some businessmen use those outlets to send direct messages, either by being hosted in one of the TV programs, interviewed in their [own] newspapers, or even writing opinion article under anonymous names".

Like in many countries, wealth and power have been concentrated at the upper class of a society, which in turn requires organised propaganda in order to normalize injustice and integrate citizens into a public moral conduct that accepts the norms enforced by elites (Herman and Chomsky 2002: 1-2). In today's Egypt, the private media market has grown strong enough to be even more influential than the state-run media; however, the two types of media outlets almost never contradict each other in terms of political discourses conveyed to the public. Alaa Zakareya says that "All [Egyptian] private newspapers and TV channels owned by businessmen has limitations for [freedom of] expression regarding the public opinion in order not to lead to a clash between the owner and the government that might harm his [non-media] businesses. Businessmen are the ones largely in control of the media. They can control advertising in newspapers and TV channels, and stopping them if necessary in the case of crossing the limits [of] criticising them or harming their businesses".

If we take a look at al-Masry al-Youm and al-Watan, the two most-circulated private newspapers in Egypt (estimated to sell about 150,000 daily copies each, however, no reliable sources available for a fully accurate data); we can see that they dominate access to information and high-profile official sources. We can also observe the interrelationships between newspapers' editors, investors, and the government. For example, al-Masry al-Youm was founded by Salah Diab, who was already the founder and main shareholder of Bico that dominates agricultural trade in Egypt. He also has had very strong relations with Israeli companies since the Camp David Accord was signed in 1978. Al-Watan was founded and board-chaired by Mohamed al-Amin, who was a top Mubarak supporter and a business tycoon with a diverse investments portfolio. Al-Amin interestingly hired Magdy al-Gallad as al-Watan's editor-in-chief. Al-Gallad, known for being politically highly connected, is actually a former editor-in-chief of al-Masry al-Youm, which - as we just mentioned earlier is owned by Diab.

The Egyptian private media market is clearly dominated by the business elite, which largely owns its news outlets and controls them. This happens through being direct managers and by delegating highly connected editors to serve the investors' interests. These interests vary between directly economic ones for corporations owned by the same investors, interests of other business groups, and indirectly interests of the political elite with its two factions: the civilian and the military. However, this exchange of mutual interests does not happen in a vacuum, as there are laws and regulations that facilitate this practice to exist and grow. 


\section{Tailoring Press Legislations}

Despite several notable changes in Egypt's press legislations from the July military coup of 1952 until today, the theme of control has always been there with the purpose of protecting those in power, whether civilian or military. Gamal Abdel Nasser (1954 - 1970) placed the press industry under the state's complete control. His presidency marked the beginning of the detachment of the Egyptian press from its main function, namely informing readers, to unconditionally supporting the state. It is this role that none of the governments since Nasser have ever undermined. Even more, they all directly and indirectly controlled and influenced the choices of appointed editors-in-chief (Nasser 1990). Journalists were - and still are under the influence of both government censorship and self-censorship out of fear that their work would not be published, or worse, they could be persecuted. Nasser once said on one occasion that there were "no restrictive laws on the press" and that journalists themselves chose to ignore certain issues due to self-censorship (Nasser 1979).

The grip over the press freedom slightly softened following the 1967 defeat of Egypt by Israel - with the purpose of absorbing some of the public's anger. However, laws that allowed the government to control the press were never revoked, so that the government could always enact them again whenever the need arose to exercise strict control again, depending on the political situation the country might be going through. Law 156 of 1960 turned journalists into public servants, and the prior Law 162 of 1958 had already given the president the right to declare a state of emergency, thus censor publications and hinder the freedom of expression if it is deemed to collide with national interests. The latter law is still in effect, however it was amended in 1980 and 1981. Although private ownership was (re)enforced by a law in 1980, the government at the time, under Sadat's rule, simultaneously enforced Law 148 (also known as the Law of Shame), which prohibited the publishing or broadcasting of pictures and texts that may offend "the dignity of the state" (Nasser 1990).

The press market was slightly "less controlled" under Mubarak, especially from the late 1990s until his ouster in 2011. However, laws were pretty much the same since Sadat, and in turn not very different from Nasser's tenure. During Mubarak's first two decades of presidency, the media faced substantial legal and regulatory challenges that limited their independence and hindered their ability to criticize and to hold the government accountable (Mendel 2011). The situation after the fall of Mubarak led to a relative freedom that allowed uncensored journalism and/or establishing new newspapers - which was due to the political chaos in the aftermath of 2011, rather than actual permanent freedom for media. I closely observed this emerging temporary window of freedom when I was in Egypt as a chief editor around the same period. Nour Magdy sheds a brief light on the period right after Mubarak's fall by saying that "Directly after Mubarak's fall, there was a good margin of freedom. However, newspapers and TV channels did not make use of it and engaged in selfcensorship. Then gradually things returned to how they were, maybe even worse". Additionally, the Egyptian Journalists Syndicate was long dominated by the Mubarak regime. In recent years and until the 2013 military coup, it witnessed a power struggle between pro and anti-Muslim Brotherhood forces. As a result, it has never been able to fully free itself from state interference. Though at several points in history the syndicate protected journalists, it can be said that it has also tolerated corruption within its ranks (Hafez 2015). 
By 2013, the press industry in Egypt had a force of 6378 journalists registered at the syndicate (Wahid 2013). Alaa Zakareya says that "Following the fall of Mubarak, many were allowed to work in the media field. And it is enough as evidence, seeing the big numbers of those who join the journalists syndicate during a three-year period since 25 January 2011, as more than 2000 journalists registered. The same number joined the syndicate in a period of six years during Mubarak's times. However, now things are going into the direction of suffocating the media". The number of journalists operating in this period was probably much higher than reported as many journalists are unregistered. By 2013, there were 56 state-run newspapers and 65 partisan ones affiliated with political groups (Wahid 2013). The latter number is now reduced to 64 due to the forcible shutdown of the Muslim Brotherhood's newspaper al-Horreya wal-Adala following the 2013 coup. There are no reliable numbers available for the privately-owned newspapers, however there are many that have been licensed following the fall of Mubarak, and I estimate that the total number is in the hundreds based on an observation of their online presence.

Toby Mendel (2011) goes through the details of journalism laws concerning issuing new private newspapers and analyses the controversy and control that remains in practice by authorities. Anyone intending to establish a newspaper must obtain a license from the Supreme Press Council (SPC). The application for a license must include various types of information, including the title, the language, periodicity, business sector, budget breakdown, sources of funding, editorial structure, nationality and place of residence of the proprietor, the name of the editor-in-chief and address of the printing house. The law also says that no one who is prohibited by law from exercising political rights may own or publish a newspaper. The SCP is required to decide on a submitted application for a newspaper license within 40 days. If an application is refused, the council is supposed to provide specific reasons for the refusal to the applicant who may then appeal to the Court of Administrative Adjudication within 30 days. However, the law does not indicate what might justify a refusal to issue a license. The law also states that obtaining a license to publish a newspaper is a "special privilege", a label that explains why such strict conditions for the establishment of private newspapers exist. These newspapers must take the form of co-operatives, owned exclusively by Egyptians, with no one owning more than 10 percent of the overall capital. It is unclear whether these rules are enforced in practice, as at least some major newspapers appear to be owned, or at least controlled, by individual businessmen (Mendel 2011). During my practice in the field, I learned that the manipulation of ownership is practiced through dividing a newspaper's capital shares among fake partners - mainly relatives and/or friends of the private newspaper's major investor. This practice applies to the two examined samples in this article: al-Masry al-Youm and al-Watan. There is no available information that the SCP ever tried to investigate such manipulations.

Moreover, the practice of having to apply for security permissions to obtain a license is essential. Although it is not mandatory by law, I witnessed that it is highly possible in Egypt, since there exists a strong culture of asking for security permission for any press activity from establishing a newspaper to holding a camera in the street. For example, a new newspaper without security permission will definitely find nowhere to print. A positive aspect of the temporary change between 2011 and 2013 was that the SCP's procedures became faster following Mubarak's fall. However, being fast or not does not mean a lot to journalists such 
as Ihsan Sameer who strongly believes that "There are no differences. The deep state is in control, and hence policies are the same". Wesam Shawkat takes an even more pessimistic position saying that 'it [the situation of media] is going from bad to worse".

As a setback from the marginal positive developments that the syndicate witnessed in the two years following Mubarak's fall, a recent update dimmed the picture even more than how it was before 2011. It is a new unified media law that is supposed to replace all the ambiguous legislations of the past. The current constitution (voted for and passed through a referendum in January 2014) mandates the formation of three media regulators. Article 211 stipulates the formation of the Supreme Media Regulatory Council, which is responsible for regulating the affairs of audio and visual media, printed and digital press and other media forms. Article 212 outlines the formation of the National Press Authority, which manages and develops state-owned press institutions. Finally, Article 213 orders the formation of the National Media Authority, which manages and develops state-owned visual, audio and digital media outlets. In accordance with the law, the Supreme Media Regulatory Council's board is composed of thirteen members, three of whom are appointed by the country's president, including the council's head. In response to these changes, the Journalists Syndicate issued a statement reiterating its call for a unified media law that would adhere to the constitution, notably Article 71, which prohibits all punitive measures curtailing freedom of the press. The syndicate's position is in contrast to many pro-state journalists and the government itself, which see the regulation as a necessary means to combat what it considers the dissemination of false news, a claim that is often deployed to challenge positions other than the government's own (Mohie 2016). Reda Abbas pessimistically says that "Unfortunately, it seems that they will bend the laws to the benefit of the regime as usual".

In the end, Egypt does not seem to be very unique in the region regarding its media legislations, which are unfriendly to freedom of expression. Examination of media legislations in other Arab countries shows that this authoritarian regulatory environment generally exists throughout the region. Given this landscape, it is unsurprising that censorship by both government and private media topped the list of many complaints brought by activists during the 2011 Arab Uprisings. Indeed, neither Egypt nor any Arab country receives a ranking of "free" on the Freedom House press index (Duffy 2014). As such, there exists a situation that ensures the prevalence of the government-friendly political discourse in the private press.

\section{Tycoons and Editors: Teaming Up}

In order to understand the interest of Egypt's business elite in controlling the private press, I will go through the business affairs of two major profiles in the sector. Understanding their backgrounds and going through their stories one by one can provide us with an extra dimension within the picture already drawn in earlier sections in order to explain this strong interest in the press, which reinforces their economic and political powers. I chose these two investors based on the top two newspapers selected for the focus of this article. The first is Salah Diab, the agribusiness tycoon, and the co-founder and CEO of al-Masry al-Youm. The 
second investor is Mohamed al-Amin, a diverse-portfolio investor and sole founder of alWatan and several other media outlets.

Salaheddin Ahmed Tawfiq Diab, known simply as Salah Diab, does not have a diverse media portfolio like al-Amin's, which will be discussed later. However, his non-media investments are much more diverse. His father, Tawfiq Diab, was a critical journalist in the first half of the twentieth century - opposing the British occupation over the country. However, it is not documented anywhere that the son ever practiced journalism before deciding to step into the sector as an investor in 2004 and launching al-Masry al-Youm. He is known to be "Israel's good business partner". The power of Diab lies in the portfolio of his family that controls about 70 percent of the American brands operating in Egypt. According to the American Chamber of Commerce, the family represents 43 American companies in the country. One of these companies is the American oilfield services giant Haliburton (AlMa'refa 2018), which is known for several overseas corruption scandals, especially in Iraq following the US invasion in 2003. Salah Diab was once briefly detained following the ouster of Mubarak and later released on bail, in a corruption case (out of 17 cases against him and others he engaged in business with). The case was about a deal between him and Mubarak's Oil Minister Sameh Fahmy, where the latter sold Diab's Pico a piece of land with potential oil investments for less than the market price.

Mohamed al-Amin, our second case in this article, came to the public sphere right after the fall of Mubarak, as he was not significantly known to the public before. His wealth was estimated at about three billion US Dollars (Kamal Eddin 2012). However, his diverse investment portfolio, from real-estate to TV networks and the press in September 2011, is considered highly non-transparent when it comes to documentation or public records. In a period of about two years, al-Amin managed to establish, buy or inject capital to what I estimated to be 14 media outlets. No clear documentation can found though. What is confirmed about his media portfolio, whether full or partial investments, are the TV networks CBC, al-Nahar, Modern, Panorama and Moga. He also bought the Cairo-based Arab News Agency from its Kuwaiti owners, and the local newspaper of al-Fagr. However, most importantly for this research, he founded al-Watan and manages it. The newspaper is now known to be Egypt's richest newspaper with the highest salaries ever paid to journalists. It is highly circulated in the journalists' community that al-Amin has heavy Kuwaiti financial support. This rumour is supported by the successful acquisition of the Arab News Agency, formerly owned by the Kuwaiti billionaire Mohamed al-Kharafi. Another indication for the Kuwaiti involvement in his sudden media investments is his many and frequent one or twoday trips from Cairo to Kuwait around the same period he was acquiring all these media companies (Kamal Eddin 2012). It is worth mentioning that alongside Saudi Arabia and the United Arab Emirates, Kuwait was a strong supporter of Mubarak and the 2013 military coup.

While investigating al-Amin's life and his origins for this research, the available information seemed conflicting and vague. What seems to be confirmed about him in media circles is that he was working as a construction site manager in Kuwait in his early career life. He later became a manager of a Kuwaiti construction company, and then returned to Egypt to start his own business. He started with an agriculture company licensed by then Agriculture Minister Youssef Wali, who is a controversial character known for his corruption and being a 
loyal Mubarak's ally who served as a minister for more than 20 years. He heavily injected investments in Amer Group, owned by his friend Mansour Amer, whom was briefly detained for several corruption cases in 2011. Regarding al-Amin's wealth and its undeclared sources, a lawyer called Tarek Mahmoud officially used "the right of reporting against citizens with suspicious wealth". However, following a brief investigation, the case was closed by the order of the pro-Military prosecutor Abdel Meguid Mahmoud (Kamal Eddin 2012), whom was hired by Mubarak and survived the uprising until October 2012.

Despite the similarities in suspicious connections, corruption allegations, and being close to Mubarak's regime and then the military, there are some differences among the two tycoons concerning their backgrounds and media practices. When I asked my interviewees to draw comparisons between the two media tycoons in question, Reda Abbas thought that "Some of them are more professional than others [in] dealing with media they own. As an example, Diab was raised [in his family] close to the media, so he understands most of the process very well. Al-Amin jumped [into the media] from elsewhere with the aim of playing a big role in no time, which raises many questions". Wesam Shawkat was very direct in his comment saying that "Salah Diab possesses enough experience to own a media institution and use it as a magical wand. Mohamed al-Amin is a façade for executing what he has been ordered to do". Nour Magdy, sees Diab as a tycoon who "Started his media activities before the revolution, which played a political role in many cases. After the revolution the political role of his media tools became more noticeable to serve his economic interests, but we cannot ignore their relations to the security services". As for Mohamed al-Amin, Magdy says that "Nobody knew him before the uprising as he entered the media field suddenly with a huge amount of money invested in al-Watan newspaper and $C B C$ [TV network]. What we know is that he represents the counter-revolution, but nobody knows which camp he belongs to in this regard. We cannot also ignore talks about relations that link him with security bodies". In a newspaper headline style, Alaa Zakareya labels the two media tycoons as follows "Diab, a media investor at the service of businessmen and their interests. Al-Amin, a façade for a capitalist block within the government for business interest".

Looking at these business tycoons from another perspective, it is useful to learn about the management capacity of members of the business elite who stepped into the media sector from different business backgrounds. We should assume that they would need someone to help them execute their media agendas professionally. And here comes the role of an editorin-chief as a media tycoon's assistant, at least for this research focusing on particularly newspapers. The media tycoon may be supported by several "assistants" who normally manage divisions or companies within the tycoon's larger interests. The assistant can be a chief executive, he may also take entrepreneurial risks, but he is not the ultimate owner or controller of the overall enterprises (Skovgaard-Petersen 2015). This article deals with Magdy al-Gallad, the current editor-in-chief of al-Watan and formerly al-Masry al-Youm as one of those assistants. He did not work for only one media tycoon, as his services are well demanded in the sector. Business tycoons seem to compete to hire him, as it happened between Diab and al-Amin, as he moved from al-Masry al-Youm to al-Watan. The list of this type of assistants is an extensive one in Egypt, but al-Gallad is a notable phenomenon worth focusing on in this article. 
Several years prior to the phenomenal rise of al-Gallad, Mohamed Hassanein Heikal, who served under Nasser as the editor-in-chief of Egypt's leading state newspaper Al-Ahram, wrote the story of his exclusive dinner invitation by the former Yemeni President Ali Abdullah Saleh during one of his visits to Egypt the 1980s. Heikal explained that Saleh was telling him about a discussion that took place between him and Mubarak earlier during the same visit regarding an issue Saleh had with the Egyptian press:

The Yemini president had expressed [to Mubarak] how annoyed he was because of an article written by a journalist (who he mentioned his name). Mubarak's response was unexpected by the Yemini president. Mubarak asked him without an introduction "Has not Yemen become an oil-producing state?" Ali Abdallah Saleh was surprised by what [Mubarak's response] seemed far from what he was talking about, however Mubarak reconnected what he interrupted and continued: "Man, shake your pocket, give him a bite and he will stop attacking you" (Kamal Eddin 2013: 43).

Mubarak's response to Saleh's complaint about the annoying journalist tells a lot about how Mubarak was dealing with the media and what type of journalism he was encouraging. He chose to corrupt critical voices rather than using his predecessors' heavy-handed punishment, which was mostly imprisonment. Corruption was already a common practice in the state-run press, when the green light was given for the private press market to form itself through the business elite, and hence the practices were transferred. I believe that our two sample newspapers in this article, al-Masry al-Youm and al-Watan, are clear representatives in this normalised financially corrupt media atmosphere since Mubarak's early years in office. It is important to note that Magdy al-Gallad is known to receive the highest monthly salary (EGP 200,000) ever paid to an editor-in-chief in the history of Egyptian journalism (Masress 2018).

As mentioned earlier, al-Masry al-Youm was founded in 2004. Many editors ran the newspaper since its foundation, but none had the power that Magdy al-Gallad (later discussed as al-Watan's editor as well) maintained, nor spent the number of years in his position (2005 - 2012). Al-Gallad started his career as an investigative journalist at the state-run Al-Ahram newspaper before he moved to al-Masry al-Youm. He was listed among the top 100 influential Arabs in 2009 by ArabianBusiness.com, and he hosted at least three TV shows (Gololy 2018). Al-Gallad effectively created a network of loyal editors and journalists over the years. These people have not necessarily been loyal to their newspapers or their profession, but mainly to him as a person. As such, their loyalty was rewarded by being appointed to higher positions in his newspaper, and al-Gallad rewarded them in other cases by finding them freelance opportunities in TV channels as program editors or as hosts using his personal connections (Kamal Eddin 2013: 159).

Al-Gallad was very famous for having close connections with Mubarak and his family, especially with Gamal, who was being prepared to inherit the power from his father at a later point. The plan, however, was interrupted by the 2011 uprising. Here is a rather bizarre passage from an article he wrote in 2009 with the titled 'Life on the Shoulders of Gamal Mubarak":

The ambitious and polite man walks his political path carrying on his shoulders savage creatures surviving on his blood, different in sizes from worms to rhinoceros and aggressive monsters. Most of whom [mentioned animals] do not like Gamal Mubarak as 
much as they are after gaining the most of political and financial gains from his own living flesh. And the man is paying the price without knowing. And the price is creating more distance between him and the average citizen (Al-Gallad 2009).

It was heard in press circles that al-Gallad warned his reporters from siding with the 2011 uprising in its first days. Sami Kamal Eddin (2013) confirms the story as he wrote, "Magdy al-Gallad stood in the newsroom in the first days of the revolution and said: Whoever wants to go to Tahrir Square to participate in the protests and the revolution should not say that he belongs to al-Masry al-Youm. Otherwise, he will be sent to the Investigations Department". I argue that this position towards the 2011 uprising is in line with al-Gallad's close relations with Mubarak's family, which clearly appears in the article quoted earlier about Gamal. However, following the fall of Mubarak, he always introduced himself as a supporter of the uprising. He also continued to claim the same support even after his move to al-Watan, although it is owned by al-Amin, who is one of the most openly anti-revolutionary members of the business elite.

During the 2013 military coup, Yasser Rizk was al-Masry al-Youm's editor-in-chief. He is known in the press circles for having a very good relationship with al-Gallad, his former superior before moving to the newly founded al-Watan in 2012. Al-Gallad clearly left one of his loyal men behind at al-Masry al-Youm before moving to al-Watan. Rizk is not as powerful or well-connected as al-Gallad is. He was quickly appointed as al-Masry al-Youm's editor once al-Gallad was chosen by al-Amin to lead the foundation process of al-Watan. Rizk graduated from the same faculty of communication as al-Gallad did in 1986. He worked as a journalist for the state-run newspaper Akhbar al-Youm since he was a student at Cairo University. He later became a military editor at the same newspaper, and then a reporter at the presidential palace until 2005. In the same year, he was appointed as the editor-in-chief of the state-run weekly magazine al-Idha'a wal-Tilfizyun. One week before the 2011 uprising broke out, he was appointed as the editor-in-chief of Akbar al-Youm but was quickly "dismissed" from the position following Mubarak's ouster. Later in August 2012, he joined al-Masry al-Youm as its editor-in-chief after al-Gallad moved to al-Watan.

Rizk ran al-Masry al-Youm exactly as al-Gallad did before him. The same policies and same editorial line continued. Rizk's journalistic career has grown mostly under the state-run press. He worked for Akhbar al-Youm before al-Masry al-Youm. In late 2013, he returned to it as he was selected as the chairman there following the coup. This was a supposedly dignifying return ordered by the military that seemed like making up for his humiliating dismissal in 2011. Rizk later wrote an opinion article for al-Masry al-Youm on the occasion of its 10th anniversary in 2014. The article was published with the title "Yasser Rizk on alMasry al-Youm: Days that Have History":

I remember each of those days with fondness and nostalgia, when I turn the pages in alMasry al-Youm's volumes in 2012 and 2013 reading through the stories and the wide coverage of the event of the year of rage under the Muslim Brotherhood's rule, going through the headlines: "Down with the Guide's rule", "The Forgers", "Illegitimate", "Morsi speaks about another country", "The country atop a crater", "Too late", and finally "30 June Revolution" and "Morsi deposed by the people's order". I testify that the founder of al-Masry al-Youm Eng. Salah Diab never got back to me because of a headline, a news story or an opinion article. At the darkest circumstances, he was a 
strongman that never bows, a supporter that never hesitates, a believer that al-Masry alYoum [the Egyptian today] would never betray the Egyptian this day or tomorrow. And what is most dear to me of those memories at al-Masry al-Youm is its exclusive first interview with then Colonel General Abdel Fattah al-Sisi; the interview that had a huge political and media role locally and internationally and hit the Muslim Brotherhood and their tails with a case of rabies [dog disease], which its barking echo is still heard (Rizk 2014).

The article above, in his own words, reveals Rizk's political and editorial biases as an editorin-chief working in the service of a media tycoon, Diab in this case, who in turn works in the service of the political (civilian and military) elite. The article almost too directly tells us about al-Masry al-Youm's position towards politics in general and the 2013 military coup in particular. Kai Hafez argues that before the military coup, Egypt was a rather immature and radically polarised but vivid public sphere. After the coup, however, he thinks that the country seems to have witnessed an authoritarian roll-back similar to that of Nasserist times. One can and must be critical of the Muslim Brotherhood, but Morsi was legitimately elected, and the military has not aimed to stabilise democracy but to seek absolute control over Egyptian politics and the economy. It seems true that the media are hardly ever the avantgarde of democratisation, because they are simply too vulnerable to political or financial manipulation (Hafez 2015).

\section{Conclusion}

The overall findings of this research, which put forward a critical review of the political economy of the Egyptian press, suggest that the interest in controlling the media sector was there as the scholarly literature and primary sources suggested and confirmed. The mainstream press succeeded in strengthening the elites' economic and political discourses, as it dealt with them as "systems of hegemony". The control has actually been there since Nasser's era (1952 - 1970), Sadat's reign (1970 - 1981) and Mubarak's tenure (1982 - 2011) which witnessed the introduction and expansion of the private press until present. There have always been legislative and conjectural changes depending on the political situation the country was going through, like Sadat's Infitah for example, where freedoms were slightly restored, however they were always minor and temporary. The research also confirms the recent interest of the business elite in the private press since 2004, which was associated with the introduction of Gamal Mubarak to the political scene. The press legislations in Egypt have always been complex and unclear, giving power to the state to control the industry since the 1950s. But since the late 1990s, the legislations favoured the business elite and the press they own. The recent "Unified Media Law" of 2017 brings even more state control over the press market. However, this control comes with less ambiguity in comparison to the previous laws that prevailed since Nasser and Sadat's eras. Profiles of the two sample private newspapers al-Masry al-Youm and al-Watan, represented by their editors-in-chief Magdy alGallad and Yasser Rizk, in coordination with both business tycoons Salah Diab and Mohamed al-Amin, also prove the interest in control by the business elite over the press market, as interviewees additionally confirm. In general, the research concludes that the political economy of the Egyptian private press, particularly in the post-Mubarak era, is 
highly controlled by the business elite in favour of themselves, the political elite and the military. Hegemony has always existed since the foundation of this market; however it was maintained and reinforced following its shake caused by the 2011 uprising. In order to achieve and maintain their hegemonic position over the economy of Egypt, the business elite engaged in a significant and direct support of the 2013 military coup.

\section{References}

Abdelrahman, Maha (2015) Egypt's Long Revolution: Protest Movements and Uprisings (New York: Routledge).

Al-Gallad, Magdy (2009) 'Al-Ḥayāh 'alā Aktāf Gamāl Mubārak' [Life on the Shoulders of Gamal Mubarak], Al-Masry Al-Youm, July 8, accessed 23 November 2018, http://today.almasryalyoum.com/article2.aspx?ArticleID=218199.

Al-Ma'refa (2018) 'Salah Tawfiq Diab', Al-Ma'refa, accessed 11 November 2018,

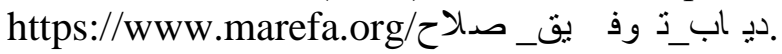

Al-Masry Al-Youm (2014) 'Yasser Rizk.. Tilmīdh al-Ustādh 'ala Miq'ad al-Mu'assis' [Yasser Rizk, student of the master on the chair of the founder], Al-Masry Al-Youm, January 2, accessed 21 November 2018, http://www.almasryalyoum.com/news/details/370054.

Benson, Rodney (2004) 'Bringing the Sociology of Media Back in', Political Communication 21 (3), pp. 103-125.

Committee for the Protection of Journalists (2015) 'China, Egypt are worst jailers of journalists worldwide', Committee for the Protection of Journalists, Accessed 6 November 2018, https://cpj.org/2015/12/china-egypt-are-worst-jailers-of-journalists-world.php.

Cook, Timothy (2006) 'The News Media as a Political Institution: Looking Backward and Looking Forward', Political Communication 23 (2), pp. 159-171.

Doyle, Gillian (2013) Understanding Media Economics, 2nd ed. (London: Sage).

Duffy, Matt J. (2014) 'Arab Media Regulations: Identifying Restraints on Freedom of the Press in the Laws of Six Arabian Peninsula Countries', Berkeley Journal of Middle Eastern \& Islamic Law 6 (1), pp. 1-31.

Entman, Robert (1993) 'Framing: Toward Clarification of a Fractured Paradigm', Journal of Communication 43 (4), pp. 51-58.

Gololy (2018) 'Magdy al-Gallad: CV', Gololy, accessed 19 November 2018. http://gololy.com/cv/ال جلاد-مجدي.

Guaaybess, Tourya (2015) 'Broadcasting and Businessmen in Egypt: Revolution Is Business', in Donatella Della Ratta, Naomi Sakr, and Jakob Skovgaard-Petersen (eds.) Arab Media Moguls (London: I.B. Tauris). 
Habermas, Jürgen (1987) The Theory of Communicative Action: Vol. 2 (Boston: Beacon Press).

Hafez, Kai (2015) 'Radically Polarized Publics and the Demise of Media Freedom in Egypt', Égypte/Monde Arabe 12 (1), pp. 37-49.

Hardy, Jonathan (2014) Critical Political Economy of the Media: An Introduction (London: Routledge).

Harvey, David (2003) The New Imperialism (Oxford: Oxford University Press).

Herman, Edward S., and Noam Chomsky (2002) Manufacturing Consent: The Political Economy of the Mass Media, 2nd ed. (New York: Pantheon Books).

Kamal Eddin, Sami (2012) 'Mohammed Al-Amin: Milliārdīr 'Fulūl' al-I'lām' [Mohammed Al-Amin: Billionaire of the Media's 'Remnants'], Al-Ahrām Al-'Arabi, December 13, accessed 17 November 2018, http://arabi.ahram.org.eg/News/17973.aspx.

Kamal Eddin, Sami (2013) Al-Șaḥāfa al-Harām [Forbidden Press] (Giza: Kayan).

Masress (2018) 'Magdy al-Gallad: EGP 700,000 end of contract from Al-Masry AlYoum and 200,000 monthly salary from al-Watan', Masress, accessed 27 November 2018, http://www.masress.com/gn4me/4086359. Sage).

McQuail, Denis (2010) McQuail's Mass Communication Theory, 6th ed. (London:

Mendel, Toby (2011) Political and Media Transitions in Egypt: A Snapshot of Media Policy and Regulatory Environment (Washington DC: Internews).

Mohie, Mostafa (2016) 'One, Two, Three, Four Media Laws: How Media Legislation in Egypt is Staging State Control', Mada Masr, 6 December, accessed 6 November 2018, https://www.madamasr.com/en/2016/12/06/feature/politics/one-two-three-four-media-lawshow-media-legislation-in-egypt-is-staging-state-control. Sage).

Mosco, Vincent (2009) The Political Economy of Communication, 2nd ed. (London:

Nasser, Munir (1979) Press, Politics, and Power: Egypt's Heikal and Al-Ahram (Ames: The Iowa State University Press).

Nasser, Munir (1990) Egyptian Mass Media under Nasser and Sadat (Columbia: Association for Education in Journalism and Mass Communication).

Ratta, Donatella Della, Naomi Sakr, and Jakob Skovgaard-Petersen (2015) Arab Media Moguls (London: I.B. Tauris).

Richter, Carola, and Gräf, Bettina (2015) 'The Political Economy of Media: An Introduction', in Nadja-Christina Schneider and Carola Richter (eds.) New Media Configurations and Socio-Cultural Dynamics in Asia and the Arab World (London: Bloomsbury). 


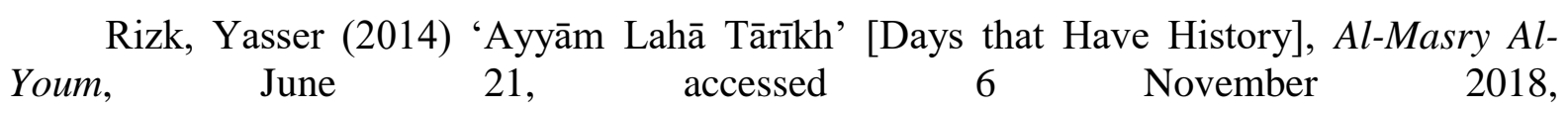
http://www.almasryalyoum.com/news/details/468406.

Skovgaard-Petersen, Jakob (2015 'An Introduction', in Donatella Della Ratta, Naomi Sakr, and Jakob Skovgaard-Petersen (eds.) Arab Media Moguls (London: I.B. Tauris).

Wahid, Maryam (2013) 'Al-Khāriṭa al-I' lāmiyya al-Misriyya ba'da al-Thawra: Arqām wa-Tashrī̄āt wa-Qaḍāāā' [The Egyptian Media Map after the Revolution: Numbers, Legislations and Issues], Al-Arabiya Studies Institute, 12 February, accessed 11 November 2018 ,

https://web.archive.org/web/20170509221740/http://www.alarabiya.net/articles/2013/02/12/2 65930.html.

Zemni, Sami, Brecht De Smet, and Koenraad Bogaert (2013) 'Luxemburg on Tahrir Square: Reading the Arab Revolutions with Rosa Luxemburg's The Mass Strike', Antipode 45 (4), pp. 888-907.

\section{Acknowledgements}

The author would like to thank Professor Sami Zemni for his support and guidance, as well as Professor Noha Mellor for her constructive criticism.

\section{About the Author}

Maher Hamoud is a lecturer of political economy at KU Leuven and a researcher at Ghent University, Belgium. His research is focused on political economy of oil, political economy of media, and EU-Middle East relations. He is also a former editor of the Cairo-based Daily News Egypt. 